\title{
Erään tieteenalan
} genealogiaa

\section{Alkuperäkertomukset ilmentävät eri tavoin tiedeseuran tarkoitusta}

\author{
Aikuiskasvatuksen tutkijat kiistelivät toista vuosikymmentä \\ siitä, puhuako tieteenalasta ja sen käytännöistä sivistyksenä \\ vai aikuiskasvatuksena. Aikuiskasvatus vakiintui ydinkäsitteeksi \\ 1950-luvun puolivälissä. Termikiistan juurisyyt ovat yhä läsnä \\ tavassa, jolla näemme aikuiskasvatustieteen tarkoituksen.
}

VUODEN 2020 LOPULLA Aikuiskasvatuksen Tutkimusseura (ATS) vietti perustamisensa 80 -vuotisjuhlaa. Näin siitä huolimatta, että seuraa ei oikeastaan koskaan perustettu sillä nimellä, vaan ATS ilmaantui vuonna 1971 osaksi suomalaisten tiedeseurojen joukkoa nimenvaihdon seurauksena (Aaltonen 2010). Vuodesta 1940 lähtien seura oli toiminut Kansansivistysopillisena yhdistyksenä.

Nimenvaihdoksessa sai samalla muodollisen päätöksensä kiista, jota oli käyty seurassa sen alkuajoista saakka. Näennäisesti kiisteltiin siitä, pitäisikö seuran toimillaan edistää kansansivistystä vai aikuiskasvatusta. Jotkut aikalaiset tulkitsivatkin, että kiista koski pelkästään sanoja. Jälkikäteen tarkasteltuna asetelma oli monimutkaisempi. Väittely termeistä peitti alleen periaatteellisia kysymyksiä, jotka nimenvaihdoksen jälkeenkin jäivät ratkaisematta. Termikiistan juuri- syyt ovat yhä edelleen läsnä tavassa, jolla näemme aikuiskasvatustieteen tarkoituksen.

Hahmotan seuran itseymmärryksen muotoutumista tukeutumalla kuvauksiin ja tulkintoihin, joita ovat esittäneet kolme keskeistä yhdistyksen kehkeytymiseen vaikuttanutta henkilöä: Helsingin työväenopiston johtaja T. I. Wuorenrinne ja tuolloiset Työväen akatemian rehtori Arvi Hautamäki ja Yhteiskunnallisen korkeakoulun kansansivistysopin opettaja Urpo Harva. Kuvausten pohjalta voi tunnistaa kolme alkuperäkertomusta, joissa yhdistyksen tarkoitus ilmenee eri tavoin.

\section{KOLME ALKUPERÄKERTOMUSTA}

Kertomuksilla ihminen tekee maailmaa ymmärrettäväksi itselleen ja muille. Erityisen kiintoisia ovat alku- 
peräkertomukset, sillä niistä käy ilmi kertojan käsitys sitä, mikä jossain ilmiössä tai asiantilassa on olennaista ja tärkeää (Aro 1999, 30-32). Yksittäisen instituution, kuten tiedeseuran, alkuperäkertomuksesta voi päätellä, millaisena sen tehtävä aikoinaan nähtiin. Mitä pidettiin tärkeänä, mitä taas vähemmän tärkeänä? Millä tavoin päämääriin oli tarkoitus pyrkiä?

Jokaisella Aikuiskasvatuksen Tutkimusseuran kanssa tekemisissä olevalla on omanlaisensa kuva siitä, miksi seura on olemassa ja mitä se tekee. Tottumuksen voima houkuttelee katsomaan seuraa selviönä, paikkaansa asettuneena ja tarkoituksensa löytäneenä.

Kun instituutio on kerran kasvanut kiinni osaksi omaa elämää, kun on oppinut sen oikut ja tottunut sen tapoihin, voi olla vaikeaa kuvitella sille mitään toisenlaista tarkoitusta, oikeutusta saati olemisen tapaa kuin se, millaisiksi sen on itse ymmärtänyt. Itsestäänselvyyksiä on vaikea tunnistaa itsestäänselvyyksiksi. Tarkentamalla katseen instituution kehkeytymishistoriaan voi kuitenkin löytää näkökulmia, jotka mahdollistavat siirtymisen totuttujen ajattelutapojen ja toimintamallien tuolle puolen. Tutkimusseuraa koskevat tyyppikertomukset on rakennettu pääosin Kansansivistys-lehdessä vuosina 1950-1954 julkaistujen kirjoitusten pohjalta.

Kansansivistystyön vaikuttaja Arvi Hautamäki sijoittaa Kansansivistysopillisen yhdistyksen syntyhetken vuoden 1940 myöhäiseen syksyyn. Kaikki alkoi keskustelusta, jota hän kävi T. I. Wuorenrinteen kanssa heidän matkatessaan linja-autossa Kauniaisista kohden Helsinkiä. Matkalla nousi esiin ajatus uudesta yhdistyksestä, joka kokoaisi yhteen kaikki vapaan kansansivistystyön toimijatahot. (Hautamäki 1953, 115.) Näistä vanhin oli Kansanvalistusseura, jonka Kirjeopisto mahdollisti omaehtoisen opiskelun kaikkialla, minne postia vain kuljetettiin. Asemansa olivat myös jo vakiinnuttaneet nuorisoseuraliike, kansanopistot ja työväenopistot. Opintokerhot ja niiden työskentelyä tukeva kirjastolaitos olivat samoin tärkeä osa kansalaisten omaehtoista sivistysharrastusta. (Esim. Inkilä 1954.)

Ongelmana oli kuitenkin kansansivistystyön kentän hajanaisuus: tekijöitä oli useita mutta ne toimivat erillään toisistaan. Tarvittiin kohtauspaikka, joka mahdollistaisi kokemusten vaihdon ja tutkimustyön alasta. Wuorenrinne lupautui kutsumaan koolle neuvottelukokouksen, jossa valmisteltaisiin kansansivistystyön kenttää kokoavan yhdistyksen perustamista. Hautamäki puolestaan levitti tietoa perustamishankkeesta sivistystyöntekijöille.

Tieto uudesta yhdistyksestä otettiin innolla vastaan. Tähän saattoi osaltaan vaikuttaa se, että professori Zachris Castrén oli 1920-1930-luvun vaihteessa ohjannut kansansivistysopillista yliopistokerhoa, jota voitiin pitää nyt perustettavan yhdistyksen esimuotona. (Hautamäki 1953; Pöytäkirja 7.12.1940, \$2). Hautamäen selonteossa seuran perustamisen tarkoitus oli saattaa yhteen kansansivistystyötä tekevät seurat, laitokset, kerhot ja opistot. Yhdistys tarjosi yhteisen tilan, joka mahdollistaisi tietojen vaihdon ja kansansivistystyön suunnitelmallisen kehittämisen.

Wuorenrinne esitti oman versionsa yhdistyksen syntykertomuksesta vuonna 1950, kymmenen vuotta yhdistyksen perustamisen jälkeen. Kun Hautamäki oli sijoittanut yhdistyksen alkuhetken vuoden 1940 loppuun, Wuorenrinne aloitti oman kertomuksensa puolta vuotta varhaisemmasta ajankohdasta, talvisodan päättymisestä.

Elämä sodan aikana oli ollut raskasta, mutta sitä se oli myös sodan päätyttyä. Uuden elämän aloittaminen oli kaikilla aloilla vaikeaa: ”Näytti siltä kuin olisi puuttunut pohja, jolle rakentaa [--] kansan oli vaikea löytää oma itsensä”. Lamaannus kosketti myös kansansivistysväkeä. Siksi oli tarpeen lyöttäytyä yhteen pohtimaan kysymyksiä, joita valtiollisen aseman muuttuminen asetti kansansivistystyön ratkaistavaksi. (Wuorenrinne 1950.)

Wuorenrinteen tapaa hahmottaa yhdistyksen tarve ja tarkoitus täydentää hänen esiintymisensä yhdistyksen perustavassa kokouksessa 7. joulukuuta vuonna 1940. Edellinen päivä oli ollut ensimmäinen sodanjälkeinen itsenäisyyspäivä, jota oli vietetty "kansallisen yhtenäisyyden ja tulevaisuudenuskon päivänä”. (Pöytäkirja 1940, 1 §.) Sota oli raivonnut Euroopassa, ja moni maa oli joutunut valloittajan miehittämäksi. Suomi oli kuitenkin selviytynyt suurvallan hyökkäyksestä säilyttäen näin vapautensa ja riippumattomuutensa. Helsingin yliopiston rehtori oli syyslukukauden avajaisissa tarjonnut selitykseksi yleistä valistustason nousua, ja erityisesti työväen omaehtoista sivistystyötä. (Pöytäkirja 1940, \$2.) Arvatenkin juuri tämä julkinen tunnustus oli 
TAVOITTEENA OLI

\section{SIVISTYNYT KANSALAINEN, \\ JOKA KYKENEE OTTAMAAN}

OSAA TULEVAISUUDEN

YHTEISKUNNAN

MUOVAAMISEEN.

innostanut Hautamäkeä ja Wuorenrinnettä ottamaan aloitteen uuden yhdistyksen perustamistyössä.

Perustettavan yhdistyksen oli määrä tehostaa kansansivistystyötä tarjoamalla alan toimijoille tilaisuus vaihtaa kokemuksia ja edistämällä "kansansivistystyön syväluotaamista" eli tutkimista. Ja jotta kokemukset ja tutkimukset hyödyttäisivät kansansivistystyötä ja sen tekijöitä, yhdistyksen oli valmistauduttava levittämään tietoja myös painetussa muodossa. Keskustelun jälkeen kokous päätti yksimielisesti perustaa Kansansivistysopillisen yhdistyksen. (Pöytäkirja 1940, \$2.)

Perustavan kokouksen pöytäkirja on sikäli merkillinen, että siinä äänen saa vain Wuorenrinne. Avaussanat ja yhdistyksen tarkoitusta esittelevä alustus vievät nelisivuista pöytäkirjasta valtaosan, kolme ja puoli sivua. Kokouksen koollekutsujana Wuorenrinne oli luonteva valinta myös yhdistyksen esimieheksi. Varaesimieheksi valittiin kanslianeuvos Niilo Liakka (Pöytäkirja 1940, \$4.) Hänen valintaansa voi pitää kunnianosoituksena kansansivistystyön vanhalle kaartille, jota kokouksessa edusti myös Väinö Voionmaa. Liakan kuoltua vuonna 1945 hänen tilalleen nousi yhdistyksen varaesimieheksi Urpo Harva.

Wuorenrinteen mukaan uuden yhdistyksen tarkoitus oli vahvistaa kansalaisten yhteydentunnetta ja valmiuksia toimia kansakuntaa koettelevan hätätilan lievittämiseksi. Vapaan kansansivistystyön tekijät oli koottava yhteen, jotta he toisiltaan oppien voisivat yhä tarmokkaammin edistää kansalaisten omaehtoisia sivistysharrastuksia. Tavoitteena oli sivistynyt kansalainen, joka kykenee ottamaan osaa tulevaisuuden yhteiskunnan muovaamiseen.

Alkuvuosina Wuorenrinne johti Kansansivistysopillista yhdistystä rehtorintyönsä ohessa. Ensimmäi- sessä kokouksessa hänet haastoi tohtori Urpo Harva, joka oli vastikään valittu kansansivistysopin opettajan virkaan Yhteiskunnallisessa korkeakoulussa (Harva 1942; Kuka kukin on 1954, 182; Tuomisto 2004). Samaa tehtävää oli vuosina 1930-1938 hoitanut sivutoimisesti Castrén (Muiluvuori 2001) ja tämän kuoltua Wuorenrinne, ja Harvaa saattoi siten pitää kummankin työn jatkajana. Kansansivistysopin teoreettiset lähtökohdat hän näki kuitenkin toisella tapaa kuin edeltäjänsä.

Harva esitti oman alkukertomuksensa yhdistyksen kolmannessa vuosikokouksessa. Esitelmässään hän totesi Wuorenrinteeseen viitaten, että yhdistyksen perustamiseen vaikutti kaksi pääpyrkimystä: Ensinnäkin tahdottiin saada aikaiseksi henkinen yhteys kansansivistystyön eri aloilla työskentelevien kesken. Toiseksi pyrkimyksenä oli käynnistää kansansivistystyön tieteellinen tutkimus, joka siihen asti oli ollut kovin vähäistä. Ensimmäisessä tehtävässä oli onnistuttu hyvin, mutta tutkimustyö oli yhä alkutekijöissään. Kolmen toimintavuoden jälkeen Harva piti tarpeellisena päättää, mihin asiakohtiin tutkimusta oli tarkoitus vastaisuudessa jatkossa suunnata. Hän arveli jäsenten olevan yksimielisiä siitä, että tutkimus oli kohdennettava ensi sijassa kysymyksiin, joilla oli merkitystä "käytännölliselle kansansivistystyölle". (Harva 1944; Hautamäki 1953, 115-116.)

Harvan näkemyksiin perustuva alkukertomus korostaa yhdistyksen tarkoitusta kansansivistystyötä koskevan tutkimuksen edistäjänä. Tämä näkyy myös hänen pyrkimyksessään selkeyttää vapaan kansansivistystyön keskeisiä käsitteitä: toimintaa olisi mahdotonta kehittää, jos epämääräinen terminologia teki asiallisen keskustelun mahdottomaksi.

Yhdistyksen alkuvuosina käynnistyneessä väittelyssä Wuorenrinne katsoi, että kansansivistystyön teoria oli rakennettava sivistys-käsitteen varaan. Harva puolestaan piti parempana rakentaa teoria aikuiskasvatuksen käsitteelle. (Hautamäki 1953, 116.) Ensin hän oli kantoineen alakynnessä, sillä käytännön kansansivistystyötä tekevät eivät termivalintaa hyväksyneet (Tuomisto 2004). Kun kansansivistysopin opettajan toimesta tuli professuuri vuonna 1946 (Kuka kukin on 1954), Harva edusti asiassa korkeinta tieteellistä auktoriteettia. 


\section{KANSANSIVISTYS VAI AIKUISKASVATUS?}

Omassa kertomuksessaan Hautamäki tyytyy toteamaan, että kansansivistystyötä tekevien kenttä oli hajanainen, minkä tähden tarvittiin yhdistys, joka mahdollistaisi tiedonvaihdon ja yhteistoiminnan toimijoiden kesken. Wuorenrinne ja Harva pohtivat myös yhdistyksen päämääriä, jolloin heidän näkemyksensä erosivat selvästi toisistaan. Tämä selittyy ainakin osaksi henkilöhistoriallisilla syillä.

Wuorenrinteelle tärkeä vaikutteiden lähde oli Zachris Castrén (1868-1938), jolla oli käytännöllisen filosofian dosentuuri. Hän hoiti useaan otteeseen professorin tehtäviä mutta ei koskaan saanut vakinaista virkaa. (Muiluvuori 2001; Huuhka 1990, 146-147.)

Yliopistotyön ohessa Castrén paneutui yhteiskunnallisten kysymysten selvittelyyn ja kannatti muun muassa uskonnonvapautta. Vuonna 1904 hän oli mukana perustamassa Nuorsuomalaista Puoluetta ja kuului K. J. Ståhlbergin tavoin sen uudistusmieliseen siipeen, "varpusiin". Castrén oli tinkimätön kansanvaltaisuuden kannattaja paheksuen konservatiivien parissa virinnyttä aietta tehdä Suomesta kuningaskunta. Hän osallistui myöhemmin Lapuan liikkeen vastaiseen kansalaistoimintaan ja rauhantyöhön. (Muiluvuori 2001.) Castrénin kiinnostus yhteiskunnallisiin kysymyksiin vei hänet vuonna 1914 vastaperustetun Helsingin suomenkielisen työväenopiston johtajaksi, mitä tehtävää hän hoiti aina kuolemaansa saakka (Huuhka 1990, 88).

Castrénin työn seuraajana filosofian maisteri Wuorenrinne oli ennen kaikkea käytännön kansansivistäjä. Edeltäjältään hän oli omaksunut sen periaatteen, että kansansivistystyön ensisijainen tehtävä oli tarjota eri kansanryhmille mahdollisuus sivistää itseään tarjoamalla heille "koeteltua tietoa". Omaehtoisen opiskelun ja ryhmissä käytävien keskustelujen avulla oli tarkoitus kehittää opiskelijoissa taitoja, joita he tarvitsivat toimiessaan täysivaltaisina kansalaisina. (Huuhka 1990, 152; Harva 1984.) Sama yhteiskunnallinen painotus ilmenee Wuorenrinteen näkemyksissä.

Harvallakin oli kokemusta kansansivistystyöstä, olihan hän toiminut opettajana kesäyliopiston ja kirjeopiston lisäksi työväenopistoissa ja kansanopistoissa. Hän oli saanut vaikutteita tapaansa hahmottaa sivis- tystyön tehtävä opettajaltaan ja väitöskirjansa ohjaajalta J. E. Salomaalta, jonka mielestä kasvatuksen viimekätinen päämäärä oli kansan ja koko ihmiskunnan edistys. Kasvatus oli kulttuuriprosessi, ja kulttuuriprosessi oli kasvatusta. Kummankin yhteisenä päämääränä oli ihmisyyden toteutuminen. Ihminen taas voi kasvaa ihmiseksi vain omaksumalla ja ja sisäistämällä ihmiskunnan ja oman kansansa henkisen kulttuurin. (Salmela 2014.) Harvakin katsoi, että vapaan kansansivistystyön tavoitteena on ihmisyys. Salomaan tapaan tulkittuna tämä tarkoittaa kulttuuriprosessin osaksi asettautumista ja sen kulkuun vaikuttamista.

Vuonna 1949 julkaistiin Kansansivistys-lehdessä Urpo Harvan artikkeli, jossa hän tarkasteli termien 'kansansivistys' ja 'aikuiskasvatus' yhtäläisyyksiä ja eroavuuksia. Aikuiskasvatuksella Harva tarkoitti kirjaimellisesti aikuisten ihmisten kasvattamista. Se oli tarpeen esimerkiksi silloin, kun tavoitteena oli kaikkien kansankerrosten kohottaminen "yli traditionaalisen tason". Perinteisistä ajattelu- ja toimintamalleista irrottautuminen edellytti siten aikuiskasvatusta. Vapaa kansansivistystyö oli aina aikuiskasvatusta, mutta aikuiskasvatuksen ei välttämättä tarvinnut tähdätä kansansivistyksen kohottamiseen. (Harva 1949, 67.)

Kansansivistyksen artikkelia voi pitää Kansansivistysopillisessa yhdistyksessä käydyn termikiistan päätepisteenä. Vuonna 1954 Wuorenrinne vielä sivusi teemaa puolustaessaan lehdessä kansansivistystyön puolueettomuuden periaatetta. Työväenopistoissa tämä näkyi sivistystyön erityisenä työväenhenkisyytenä. Kirjoituksen varsinainen ydin oli arvostella Harvan esillä pitämää ihmisyyden käsitettä, jota Wuorenrinne piti liian epämääräisenä - riippuihan sen merkityssisältö siitä, "kuka on sen kulloinkin kirjoittanut lippuunsa”. (Wuorenrinne 1954, 27-28.)

\section{YHTEISTOIMINNAN EDISTÄJÄSTÄ TULEE TIEDESEURA}

Vuonna 1954 Wuorenrinne siirtyi syrjään Kansansivistysopillisen yhdistyksen johdosta, ja hänen tilalleen valittiin Harva. Samalla yhdistyksen tehtävä nimenomaan tiedeseurana vahvistui. Noihin aikoihin saakka alan tieteellisestä tutkimuksesta ja tutkimusmenetelmien kehittämisestä ei ollut vastan- 
IHMISYYDEN KÄSITE J ̈̈TTI

\section{AIKUISKASVATUKSEN \\ TEOREETTISEEN PERUSTAAN}

VAIKEASTI PAIKATTAVAN

AUKON.

nut yhdistys vaan Yhteiskunnallisen Korkeakoulun kansansivistysopin oppiaine. Vuosien 1940-1954 Kansansivistysopillinen yhdistys muistutti siten enemmän sivistystyöntekijöiden kerhoa kuin alan tieteelliseen tutkimukseen paneutuvien ihmisten yhteenliittymänä. Tutkimus jäi muun toiminnan sivujuonteeksi, ja moni tuntuikin ajattelevan, että sen olisi sovittauduttava niihin puitteisiin, jotka vapaan sivistystyön traditio sille tarjosi. Siten Wuorenrinteen ja Harvan persooniin kiinnittynyt "sanojen kiista" koski pikemminkin sitä, pitikö alaa koskevan tutkimuksen sovittautua kansansivistystyön ajan myötä kehittyneisiin käsitteellisiin ja toiminnallisiin raameihin.

Urpo Harvan myötä yhdistyksen toiminnassa korostui alan tieteellinen asiantuntemus. Institutionaaliset muutokset tukivat yhdistyksen kehittymistä tiedeseuraksi. 1960 Yhteiskunnallinen Korkeakoulu muutti Helsingistä Tampereelle ja muodosti näin kasvualustan tulevalle Tampereen yliopistolle. Vuonna 1965 oppiaineen nimi muuttui kansansivistysopista aikuiskasvatukseksi, ja Harvasta tuli aikuiskasvatustieteen professori.

Vuonna 1971 seuran nimi lopulta vaihtui Aikuiskasvatuksen Tutkimusseuraksi. (Tuominen 2004). Nimenvaihdos ei ollut pelkästään terminologista hienosäätöä, sillä aikuiskasvatuksen käsite teki mahdolliseksi tarkastella kaikenlaista aikuisiin kohdistuvaa kasvatustyötä. Aiemmin yhdistyksen ytimessä ollut vapaa sivistystyö jäi aikuiskasvatustieteen yhdeksi osa-alueeksi.

Harvan yritys selkeyttää alan terminologiaa ei kuitenkaan edennyt kyllin pitkälle. Ihmisyyden käsite jätti aikuiskasvatuksen teoreettiseen perustaan vaikeasti paikattavan aukon. Tämä paljastuu kysyttäessä, mikä mahtaa olla julkisvallan tukeman vapaan sivistystyön tarkoitus. Onko sen päämäränä yksilöllisten oppimistarpeiden tyydyttäminen vai aktiivista kansalaisuutta ja demokratian jatkuvuutta edistävän kansalaissivistyksen kohottaminen? Ja ylipäätään, onko kaikki aikuisten kanssa tapahtuva ja oppimiseen tähtäävä puuhastelu luettava automaattisesti aikuiskasvatuksen alaan?

Epätietoisuus suomalaisen aikuiskasvatuksen perimmäisestä tarkoituksesta tekee mahdolliseksi sisällyttää käsitteen alle suuntauksia, joita ei niinkään yhdistä jaettu ymmärrys siitä hyvästä, jota aikuiskasvatuksessa olisi tavoiteltava kuin se, että kasvatukselliset toimet kohdistuvat siihen se väestönosaan, jota kutsutaan aikuisiksi.

Asetelma on aikuiskasvatustieteen kannalta ongelmallinen. Filosofi Ilkka Niiniluodon muotoilemassa tieteiden taksonomiassa aikuiskasvatustiede voidaan lukea kuuluvaksi suunnittelutieteisiin (ks. esim. Okko 1988). Suunnittelutieteen itseymmärrykseen sisältyy välttämättä tieto siitä, miksi tieteenala on olemassa; mikä on se 'hyvä', johon on tarkoitus pyrkiä. Jos tarkoitusta ei tunnisteta tai tunnusteta, suunnittelutieteen parissa tehtävä tutkimus uhkaa rappeutua tiedettä muistuttavaksi puuhasteluksi, jossa tieteenalan olemusta määrittävän 'hyvän' asettaa tiedeyhteisön sijaan jokin ulkopuolinen taho. Käytännössähän tämä tapahtuu tutkimusrahoitusta kohdentamalla.

\section{MENNEEN JÄLJET MEISSÄ}

Alkukertomukset auttavat hahmottamaan tutkimusseuran paikkaa tieteiden kentässä ja yhteiskunnassa. Mennyt ei elä vain yksilöllisessä vaan myös kollektiivisessa tietoisuudessa. Niin myös 1940-luvun termikiista on läsnä, kun tunnistamme asiantiloja ja ilmiöitä juuri aikuiskasvatukseen kuuluviksi. 'Kansansivistyksen' korvaaminen 'aikuiskasvatuksella' merkitsi etääntymistä kansansivistystyön kentästä. Aikuiskasvatuksen tehtävää ja tarkoitusta koskeva keskustelu jäi kuitenkin ratkaisematta. Työväenopistojen tarkoitus oli estää yhteiskunnan kahtiajako. Kun omana aikanamme jakolinjat ovat taas syvenemässä, saattaisi olla tarpeen miettiä, mitä haittaa käytännön aikuiskasvatustyölle ja tieteenharjoittamiselle on siitä, jos aikuiskasvatuksen olemassaolon tarkoitusta ei kyetä selkeästi sanallistamaan. 
Kahdeksan vuosikymmenen perspektiivi on sopiva etäisyys arvioida uudelleen aikuiskasvatuksen ja sitä tutkivan tieteen teoreettisia lähtökohtia arvoperustoineen. Vähintäänkin olisi hyvä päästä yhteisymmärrykseen siitä, onko ylipäätään mahdollista muotoilla aikuiskasvatukselle sellaista arvoperustaa, jossa sivistyksen ja ihmisyyden kaltaisten haperoiden termien sijaan puhuttaisiin asioista. Ihmisen aiheuttamien ympäristöuhkien ja murenevien demokratioiden aikakaudella alkaa väkisinkin pohtia, mikä voisi olla se 'hyvä', johon aikuiskasvatus on pyrkimässä.

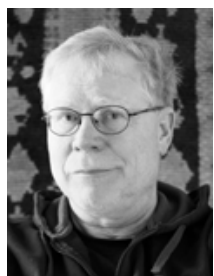

RISTO IKONEN

$\mathrm{KT}$, yliopistonlehtori

kasvatustieteen ja aikuiskasvatustieteen oppiaine Itä-Suomen yliopisto

\section{LÄHTEET}

Aro, J. (1999). Sosiologia ja kielenkäyttö. Retoriikkaa, narratiivi, metafora. Acta Universitatis Tamperensis 654. Tampereen yliopisto.

Aaltonen, R. (2010). Sivistyksellistä syvämuokkausta oma yhdistys kokosi voimat. Aikuiskasvatus 30(4), 244-246. https://doi.org/10.33336/aik.93890

Harva, U. (1942). Kansansivistystyön käsite. Kansansivistysopillisen yhdistyksen vuosikirja 1942, 3-17.

Harva, U. (1944). Kansansivistysopillisen yhdistyksen tehtävä. Kansansivistysopillisen yhdistyksen vuosikirja 1944, 26-41.

Harva, U. (1949). Vähäsen kansansivistyksen ja aikuiskasvatuksen käsitteistä. Kansansivistys 3/1949, 64-67.

Harva, U. (1984). Toivo Ilmari Wuorenrinne. Aikuiskasvatus 4(2), 111-112. https://doi. org/10.33336/aik.96347

Hautamäki, A. (1953). Kansansivistysopillisen yhdistyksen toiminnan elvyttäminen. Kansansivistys 4/1953, 115-118.

Huuhka, K. (1990). Kansalais- ja työväenopistotoiminnan historia. Helsinki: Kansalais- ja Työväenopistojen liitto.

Inkilä, A. (1954). Silmäys vuoden 1953 vapaaseen kansansivistystoimintaan. Kansansivistys 1/1954, 10-13.

Kallenautio, J. (2016). Wuorenrinne, Toivo Ilmari (1892-1984). Kansallisbiografia. Studia Biographica 4. Helsinki: Suomalaisen Kirjallisuuden Seura. https://kansallisbiografia-fi.ezproxy.uef.fi:2443/ kansallisbiografia/henkilo/7653 (14.11.2020).
Kuka kukin on (1954). Kuka kukin on - Aikalaiskirja. Henkilötietoja nykypolven suomalaisista. Helsinki: Kustannusosakeyhtiö Otava.

Muiluvuori, J. (2001). Castrén, Zachris. Kansallisbiografia. Studia Biographica 4. Helsinki: Suomalaisen Kirjallisuuden Seura. http://urn.fi/urn:nbn:fi:skskbg-005352 (13.10.2020).

Okko, M. (1988). Suunnittelutieteellisestä lähestymistavasta kirjastotieteen ja informatiikan tieteenharjoituksessa. Kirjastotiede ja informatiikka (4), 105-111.

Pöytäkirja (1940). Joulukuun 7. päivänä pidetyn Kansansivistysopillisen Yhdistyksen perustavan kokouksen pöytäkirja. https:// www.aikuiskasvatuksentutkimusseura.fi/@ Bin/119374/8BCB16EDd01.pdf

Salmela, M. (2014). Salomaa, Jalmari Edvard. LogosEnsyklopedia. http://filosofia.fi/node/2410/ (19.10.2020).

Tuomisto, Jukka (2004). Harva, Urpo. Kansallisbiografia. Studia Biographica 4. Helsinki: Suomalaisen Kirjallisuuden Seura. http://urn.fi/urn:nbn:fi:skskbg-008218 (19.10.2020).

Wuorenrinne, T. I. (1950). Kansansivistysopillinen yhdistys 10-vuotias. Kansansivistys 4/1950, 73-75.

Wuorenrinne, T. I. (1954). Eräitä reunahuomautuksia. Kansansivistys 2/1954, 27-20. 